ISSN 1112-9867

\title{
OCCURRENCE AND BIOREMEDIATION OF ANTHRACENE IN THE ENVIRONMENT
}

\author{
A. N. Z. Abidin ${ }^{1}$, S. A. Talib ${ }^{2}$, S. Alias ${ }^{3}$ and C. C. Tay ${ }^{1,2, *}$ \\ ${ }^{1}$ Faculty of Applied Science, UniversitiTeknologi MARA, 40450 Shah Alam, Selangor, \\ Malaysia \\ ${ }^{2}$ Faculty of Civil Engineering, UniversitiTeknologi MARA, 40450 Shah Alam, Selangor, \\ Malaysia \\ ${ }^{3}$ Faculty of Civil Engineering, UniversitiTeknologi MARA, 13500 PermatangPauh,Pulau \\ Pinang, Malaysia
}

Published online: 10 November 2017

\begin{abstract}
Occurrence of PAH in the environment has been a concern of many environmentalists for its obstinac, toxicity and harm that it may impose. Anthracene is a common low molecular weight PAH that is often used as a model PAH in bioremediation study due to its structure that is also found in high molecular weight PAH. This article provides an overview of the occurrence of PAH and specifically, anthracene. Due to the harm that they impose, several methods have been applied to overcome the problem, including opting for bioremediation. This article will explore on the bioremediation process involving microorganisms and the respective enzymes secreted during the process. Proposed mechanism on degradation of anthracene by bacteria and fungus are also included. The paper will further leads to gaps of study and to the direction for future study and applications.
\end{abstract}

Keywords: anthracene; bacteria; fungus; microorganisms; polycyclic aromatic hydrocarbon (PAH).

Author Correspondence, e-mail: taychiay@gmail.com

doi: http://dx.doi.org/10.4314/jfas.v9i6s.17 


\section{INTRODUCTION}

PAHs are polycyclic aromatic hydrocarbons having at least two fused benzene ring arranged in a linear, angular or clustered manner [1]. There are 16 PAHs listed by USEPA [2]. Their physical characteristics include low solubility in water, high melting and boiling points and low vapor pressure. Generally, the higher the molecular weight of a PAH, its melting and boiling point increase while vapor pressure and solubility in water, decrease[3]. PAHs are also toxigenic, genotoxic, mutagenic and carcinogenic [4]. Due to these characteristics, the release of polycyclic aromatic hydrocarbons (PAHs) into air, soil, water and marine environment concerns environmentalists for the harm PAHs impose.

PAHs are introduced into the environment through various ways that branch into anthropogenic and natural sources [5]. Its presence in the environment however is exacerbated by anthropogenic activities [6]. PAHs may undergo various fates in the environment that include volatilization, photo-oxidation, chemical oxidation, adsorption by soil particles, leaching and microbial degradation [7-8]. Physical and chemical methods are also applied for effective removal of PAHs. Bioremediation, an alternative to conventional methods has been extensively explored for its potential to remove PAHs from the environment [9].

Anthracene, as seen in Fig. 1 is a three-ring linear PAH isomeric with phenanthrene which is arranged in an angular manner.<smiles>c1ccc2cc3ccccc3cc2c1</smiles>

Fig.1.Anthracene structure

Although it is a low molecular weight PAH listed by USEPA as priority pollutant, it is not acutely toxic, carcinogenic or mutagenic $[6,10]$. Anthracene however, attacks the skin, stomach, intestines and the lymphatic system upon entering the body system [11]. Anthracene is often chosen as model PAH in various bioremediation studies because its structure is also found in benzo(a)anthracene and benzo(a)pyrene[12].

\section{OCCURRENCE OF ANTHRACENE IN THE ENVIRONMENT}

Major source of PAHs entering the environment is from the incomplete combustion of organic 
materials [13]. The increase of anthropogenic activities has also led to the widespread of PAH infiltrating the environment [14]. Industrial sites are usually associated with high PAH contamination due to activities such as processing, combustion and disposal of fossil fuels with regards to spills and leaks from storage tanks [15]. Anthracene and its methyl derivatives are common pollutants in cigarette smoke, coal liquefaction product, diesel exhaust and shale oils [16]. It is also found in soil, natural water, sediments, sewage or wastewater treatment plant, in the atmosphere and even in food [17]. According to [18], more than $95 \%$ of anthracene can be found in water while less than $1.4 \%$ can be found in atmosphere. When anthracene is released in soil, it will not leach into ground water but binds to soil particles instead.

\section{REMOVAL AND BIODEGRADABILITY OF PAH AND ANTHRACENE}

Removal, alteration or isolation of pollutants through excavation, incineration or containment have been applied for PAH removal. However, these methods are expensive and often involve transferring $\mathrm{PAH}$ from one phase to another. Alternatively, biodegradation offers an inexpensive and practical solution to the problem by transforming PAH to its less or non-toxic metabolites. The method requires much less input of chemicals and energy [19].

PAH degrading organisms span across both plant and animal kingdom that often involves microbes that are mostly bacteria, algae or fungi. Biodegradation occurs by breaking down of organic compounds through biotransformation into less complex metabolites or through mineralization into water, carbon dioxide or methane [7].

Fig. 2 shows the proposed pathway of biodegradation of anthracene[12]. Biodegradation of anthracene involved two major pathways with various metabolites in between. Continuous reaction resulted either 9,10-anthraquinone, 1-methoxy-2-hydroxyathracene, 3-(-2-carboxyvinyl)naphthalene-2-carboxylic acid or 6-7-benzo(a)coumarin which finally proceeded to ring fission process. 


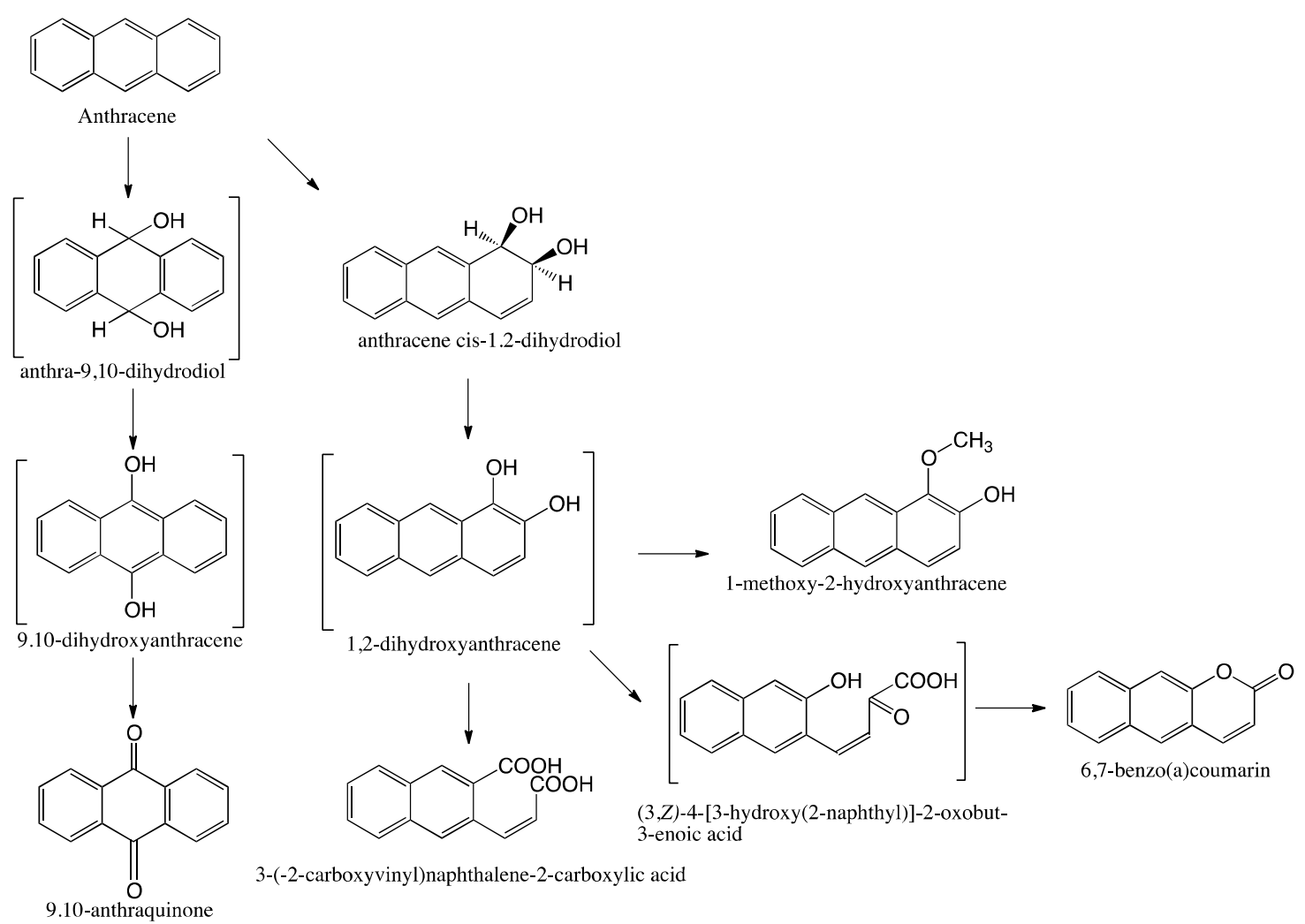

Fig.2. Proposed pathway of anthracene biodegradation [12]

Anthracene undergoes various fates when it is released into the environment. When it is found in natural water, photodegradation occurs. This process is influenced by numerous factors such as intensity of solar radiation, time of the day, latitude of the site, depth and turbidity of water bodies. When water turbidity is high, the rate of photodegradation is slower due to light scattering and the low intensity of sunlight reaching the pollutant. Anthracene trapped in sediment from adsorption on the other hand, would not photodegrade as a result of insufficient light [20]. Anthracene had shorter half-life with high exposure of sunlight[17].

Very limited evidence is available for phytoremediation of anthracene in soil environment, as compared to degradation by bacteria or fungi. Both bacteria and fungi have been widely explored for their xenobioticsdegradation including PAHs. However, due to different adaptability, factors including $\mathrm{pH}$, temperature, oxygen, microbial population, degree of acclimation, accessibility of nutrients, chemical structure of compounds or cellular transport properties are to be considered to determine the rate of biodegradation of an organism [7].

Table 1 shows the common parameters considered for bioremediation study and respective effects on biodegradation activity. Table 2 shows the maximum effect of parameters on 
biodegradation performance. The parameters involved posed a significant impact on biodegradation of pollutant $[9,21-23]$. The optimum conditionsfor biodegradation process result in maximum pollutant degradation.

Table 1. Parameters considered for biodegradation study

\begin{tabular}{cl}
\hline Parameters & Effects \\
\hline Temperature & Degradation velocity \\
Water content & Pollutant and degraded product transport \\
$\mathrm{pH}$ & Excretion of extracellular enzymes crucial for \\
& bioremediation activity \\
Redox potential & Determines pathway and efficiency of degradation \\
Solubility, Sorption, Volatility, & Relates to bioavailability of pollutants to the reach \\
Occlusion & microorganisms \\
Nutrient & Improve growth and reproduction of microbes \\
Co-contaminant & Enhance or inhibit bioremediation \\
Microbial communities & Determines the bioremediation rate \\
Co-substrate & Enable co-metabolic transformation of contaminant \\
\hline
\end{tabular}

Table 2. Parameters effect on biodegradation by different organism

\begin{tabular}{|c|c|c|}
\hline Parameters & Types of Organisms & $\begin{array}{c}\text { Maximum Effect of } \\
\text { Bioremediation }\end{array}$ \\
\hline \multirow[t]{8}{*}{ Concentration of oil } & Bacteria & \\
\hline & Nostochatei & \\
\hline & Pseudoalteromonas sp., & \\
\hline & Reugeria sp., Exiguobacterium & \\
\hline & sp., Acinetobacter sp. & Maximum at low \\
\hline & Fungus & concentration of oil in the \\
\hline & Penicillium commune & media. \\
\hline & Candida tropicalis & \\
\hline \multirow[t]{2}{*}{ Temperature } & Bacteria & \\
\hline & Nostochatei & Max at $28^{\circ} \mathrm{C}$ \\
\hline
\end{tabular}


Pseudoalteromonas sp.,

Reugeria sp., Exiguobacterium

sp., Acinetobacter sp.

Penicillium commune

Candida tropicalis

Degradation period

\begin{tabular}{|c|c|c|}
\hline & Nostochatei & 7 days for $2 \%(\mathrm{w} / \mathrm{w})$ waste \\
\hline & Pseudoalteromonas sp., & lubricant \\
\hline & Reugeria sp., Exiguobacterium & 30 days for $0.5-4.0 \%(\mathrm{v} / \mathrm{v})$ \\
\hline & sp., Acinetobacter sp. & waste motor oil \\
\hline & Fungus & \\
\hline & Penicillium commune & 15 days for $1 \%(\mathrm{v} / \mathrm{v})$ spent \\
\hline & & engine oil \\
\hline & Candida tronicalis & 10 days for $1-75 \mu \mathrm{L}$ of \\
\hline & & industrial oil \\
\hline & & 3 days for $5.3 \%$ of \\
\hline & & hydrocarbon consumption \\
\hline $\mathrm{pH}$ & Bacteria & \\
\hline & Nostochatei & Max at $\mathrm{pH} 7.5$ \\
\hline & Pseudoalteromonas sp., & Max at $\mathrm{pH} 8.0$ \\
\hline & Reugeria sp., Exiguobacterium & \\
\hline & sp., Acinetobacter sp. & \\
\hline & Fungus & \\
\hline & Penicillium commune & Max at $\mathrm{pH} 5.5$ \\
\hline & Candida tropicalis & Max at $\mathrm{pH} 8.0$ \\
\hline
\end{tabular}

Fungus

Max at $27^{\circ} \mathrm{C}$

Max at $30^{\circ} \mathrm{C}$

Bacteria

Nostochatei

Max at $30{ }^{\circ} \mathrm{C}$

\subsection{Bioremediation of Anthracene by Bacteria}

Bacteria are a class of microbes well-established in the field of bioremediation. Most of the involved bacteria are isolated from the contaminated site. Long-term exposure of bacteria to the contaminants enables them to tackle to a considerable extent [24]. Several bacterial strains 
have been reported in degrading PAH including Rhodococcus sp., Alteromonas sp., Cycloclasticus, Arthrobacter, Bacillus, Mycobacterium sp. and Pseudomonas sp. [25-26]. Bacillus, Escherichia and Mycobacterium are common bacterial strains that have been reported to degrade not only anthracene and several other PAHs in the presence of heavy metals, but lighten the burden brought by heavy metals [24].

The two key steps in bacterial degradation of PAH are initial oxidative attack followed by cleavage of benzene ring [27]. The oxidative attack leads to formation of diol, ring cleavage and eventually dicarboxylic acid. Common bacterial strains found in marine environment are Pseudomonas, Acinetobacter, Nocardia, Vibro and Achromobacter[28]. In [7] reported that a $98 \%$ reduction of total PAH content was achieved in 6 months by mixed microbial culture of bacteria from genera Acenitobacter and Klebsiella. Another study of [29] on the other hand reported Rhodococcus sp. isolated from sediments of River Grand Calumet had initial reaction rates of $0.47 \mu \mathrm{gL}^{-1}$ for anthracene mineralization. In another study, a group of bacteria successfully degraded $57.1 \%$ of naphthalene, $82.1 \%$ of phenanthrene and $55.2 \%$ of anthracene[30]. Meanwhile, in[12] also reported that Mycobacterium sp. strain PYR-1 exposed to anthracene successfully degraded $92 \%$ of the pollutant after 14 days of incubation. 3-(2-carboxyvinyl)naphthalene-2-carboxylic acid and 6,7-benzocoumarin were detected as anthracene's metabolites after degradation process.

These studies are examples that bacterial strains are capable of degrading and using pollutants as an alternative solution to conventional PAH removal methods.

\subsection{Bioremediation of Anthracene by Fungi}

Just like bacteria, fungiare microorganisms that degrade PAH. Lignolytic fungi produce extracellular enzymesthat areinduced by irregular structure of lignin. For this reason, the lignolytic system by this strain has low substrate specificity and hence capable of degrading different types of compounds. Enzymes associated with the system are lignin peroxidase, manganese dependent peroxidase, laccase and hydrogen peroxide-producing enzyme [7]. Fungi present a great potential for bioremediation because of its biomass production and excessive growth. An advantage that puts fungi ahead of bacteria is that fungi do not require preconditioning to the pollutant [31]. Isolated Aspergillusfumigatus from contaminated site degraded $65 \%$ of anthracene when the condition was set at $\mathrm{pH} 5.0$ to 7.5 and temperature at 
$30{ }^{\circ} \mathrm{C}[32]$. The study also proposed a pathway for anthracene degradation, which resulted into phthalic acid, as shown in Fig. 3 [32].

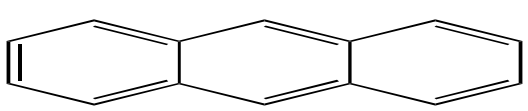

Anthracene

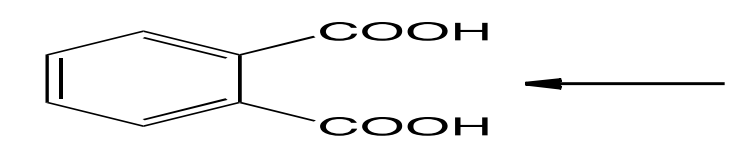

Phthalic acid

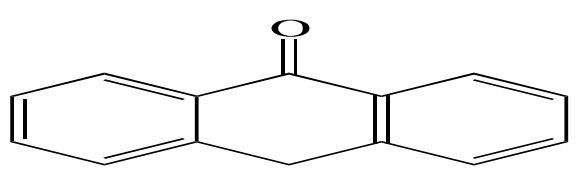

Anthrone

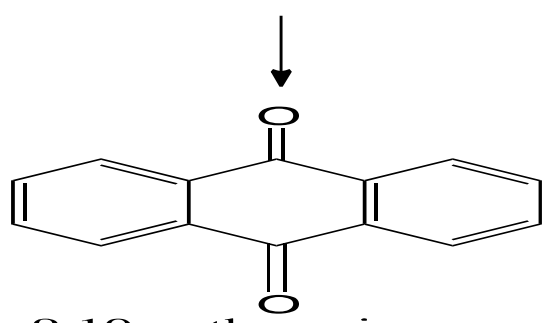

9.1O-anthraquinone
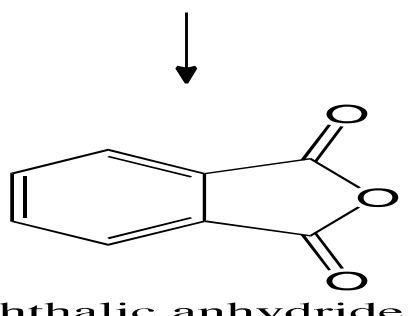

Phthalic anhydride

Fig.3.Proposed anthracene degradation pathway [32]

In [33] reported that strains from genera Bjerkandera, Phanerochaete, Ramaria andAgaricales were capable of transforming anthracene to anthraquinone but as a dead-end metabolite. In another study, a total of 40 strains isolated from an artificial wetland with most of the strains degraded $0.01 \mathrm{~g} \mathrm{~L} \mathrm{~L}^{-1}$ anthracene at different rates under liquid cultivation conditions. Ulocladiumchartarum and Absidiacylindrospora were the most efficient strains by degrading more than $80 \%$ during treatment period [34]. White rot fungi for example, employs lignin degradation system for bioremediation process [7]. Many PAHs possess 'Bay region' and 'K region', which are sites for formation of bay and K-region epoxides. These epoxides are highly reactive [35]. Table 3 shows the degradation of anthracene by various fungal strains, the metabolites resulted from the degradation and the enzymes involved in the process [34, 36-37]. Enzymes as indicated in Table 3 are fundamental in degradation of PAH process when fungi are involved. Enzymes play a role by bindingto PAH at a specific region, before the metabolites are further degraded by ring fission process. From the studies mentioned previously, it is evident that fungal strains are useful to overcome the increasing abundance of $\mathrm{PAH}$ in the environment. 
Table 3. Fungal strains and enzymes involved in degradation resulting in anthracene metabolites

\begin{tabular}{|c|c|c|}
\hline Fungal Strain & Enzymes & PAH Metabolites \\
\hline Phanerochaetechrysosporium & $\begin{array}{l}\text { Lignin peroxidase } \\
\text { (LiP) }\end{array}$ & 9,10 -Anthraquinone \\
\hline Anthracophyllum discolor & $\begin{array}{c}\text { Mn-dependent } \\
\text { peroxidase (MnP) }\end{array}$ & Not determined \\
\hline Strophariacorronila & $\begin{array}{c}\text { Mn-dependent } \\
\text { peroxidase (MnP) }\end{array}$ & 9,10-Anthraquinone \\
\hline Pleurotusostreatus & Laccase (LAC) & 9,10-Anthraquinone \\
\hline Trametesversicolor & Laccase (LAC) & 9,10 -Anthraquinone \\
\hline $\begin{array}{l}\text { Bjerkanda genera, Phanerochaete } \\
\text { genera, Ramaria genera, Agaricales }\end{array}$ & $\begin{array}{c}\text { Mn-dependent } \\
\text { peroxidase (MnP) }\end{array}$ & 9,10-Anthraquinone \\
\hline genera & & \\
\hline Aspergillusfumigatus & $\begin{array}{l}\text { Lignin peroxidase } \\
\text { (LiP) }\end{array}$ & $\begin{array}{c}\text { Phthalic anhydride, anthrone } \\
\text { and anthraquinone }\end{array}$ \\
\hline Ulocladiumchartarum & $\begin{array}{l}\text { Cytochrome P-450 } \\
\text { monooxygenase }\end{array}$ & Not stated \\
\hline Absidiacylindrospora & $\begin{array}{c}\text { Cytochrome P-450 } \\
\text { monooxygenase }\end{array}$ & Not stated \\
\hline
\end{tabular}

\section{CONCLUSION}

Opting for solutions to overcome the increasing amount of PAHs in the environment is essential for sustainability of the world. An economical, non-environmental destructive method must be employed instead of the current conventional methods that are expensive and produce secondary pollutant. Anthracene is proven to be biodegradable and various potential microorganisms can be utilized to achieve biodegradation objective. The outcome of these studies will give an understanding on how biodegradation of anthracene commences and further contributes on potential for future studies. 


\section{ACKNOWLEDGEMENTS}

We would like to acknowledge the financial support granted by Fundamental Research Grant Scheme (FRGS) 600-RMI/FRGS5/3(26/2015) and facilities support from UniversitiTeknologi MARA (UiTM).

\section{REFERENCES}

[1] Abdel-Shafy H I, Mansour M S M. A review on polycyclic aromatic hydrocarbons: Source, environmental impact, effect on human health and remediation.Egyptian Journal of Petroleum, $2015,25(1): 107-123$

[2]Ball A S, Haleyur N, Koshlaf E, Mansur A A, Morrison P D, Osborn A M, Shahsavari E. Comparison of rapid solvent extraction systems for the GC-MS/MS characterization of polycyclic aromatic hydrocarbons in aged, contaminated soil. methodsx, 2016, 3:364-370

[3] Albers P H. petroleum and individual polycyclic aromatic hydrocarbons.G. A. Burton-Jr., J. Cairns-Jr., D. J. Hoffman, \& B. A. Rattner (Eds.),Handbook of ecotoxicology. Florida: Lewis Publishers, 2003, pp. 341-371

[4] Grimmett P E, Lam Y W, Porollo A, Syed K, Yadav J S. CYP63A2, a catalytically versatile fungal P450 monooxygenase capable of oxidizing higher-molecular-weight polycyclic aromatic hydrocarbons, alkylphenols, and alkanes.Applied and Environmental Microbiology, 2013, 79(8):2692-2702

[5] Chen Y, JiaR, Yang S. Distribution and source of polycyclic aromatic hydrocarbons (PAHs) in water dissolved phase, suspended particulate matter and sediment from Weihe river in Northwest China. International Journal of Environmental Research and Public Health,2015, 12(11):14148-14163

[6] Gao Y, Goikavi C, Kang F, Ling W, Waigi M G. Phenanthrene biodegradation by sphingomonads and its application in the contaminated soils and sediments: A review. International Biodeterioration and Biodegradation, 2015, 104:333-349

[7] Haritash A K, Kaushik C P. Biodegradation aspects of Polycyclic Aromatic Hydrocarbons (PAHs): A review. Journal of Hazardous Materials, 2009, 169(1-3):1-15

[8] Jones K C, Wild S R. Polynuclear aromatic hydrocarbons in the United Kingdom environment: A preliminary source inventory and budget. Environmental Pollution, 1995, 
88(1):91-108

[9] Bunnag S, Pimda W. Biodegradation of waste motor oil by Nostoc hatei strain TISTR 8405 in water containing heavy metals and nutrients as co-contaminants. Journal of Industrial and Engineering Chemistry, 2015, 28:117-123

[10] Bohatier J, Bonnet J L, Dusser M, Guiraud P, Kadri M, Laffosse J, Steiman R. Assessment of anthracene toxicity toward environmental eukaryotic microorganisms: Tetrahymena pyriformis and selected micromycetes.Ecotoxicology and Environmental Safety, 2005, 60(1):87-100

[11] Das P, Mukherjee S, Sen R. Improved bioavailability and biodegradation of a model polyaromatic hydrocarbon by a biosurfactant producing bacterium of marine origin. Chemosphere, 2008, 72(9):1229-1234

[12] Doerge D R, Freeman J P, Moody J D. Degradation of phenanthrene and anthracene by cell suspensions of mycobacterium sp. strain PYR-1. Applied and Environmental Microbiology, 2001, 67(4):1476-1483

[13] Brown R J C, Jahan S A, Kabir E, Kim K H. A review of airborne polycyclic aromatic hydrocarbons (PAHs) and their human health effects. Environment international, 2013, $60: 71-80$

[14] Chakraborty J,Das S, Dash H R, Raj R, Mangwani N. Heavy metals and hydrocarbons: Adverse effects and mechanism of toxicity. In S.Das (Ed.), Microbial biodegradation and bioremediation. London: Elsevier,2014, pp. 24-54

[15] Juhasz A L, Naidu R. Bioremediation of high molecular weight polycyclic aromatic hydrocarbons: A review of the microbial degradation of benzo[a]pyrene. International Biodeterioration and Biodegradation, 2000, 45(1):57-88

[16] Campbell W L, Cerniglia C E, Evans F E, Freeman J P, Fu P P. Stereoselective fungal metabolism of methylated anthracenes. Applied and Environmental Microbiology, 1990, 56(3):661-668

[17] United States Environmental Protection Agency (USEPA). Health and environmental effects profile for anthracene. Washington DC: USEPA, 1987

[18] Cheung B, Mackay D, Neely W B, Paterson S.Evaluating the environmental behavior of chemicals with a level III fugacity model. Chemosphere, 1985, 14(3-4):335-374 
[19] Lee H, Providenti M A, Trevors J T. Selected factors limiting the microbial degradation of recalcitrant compounds. Journal of industrial Microbiology, 1993, 12(6):379-395

[20] Schlotzhauer P F, Zepp R G. Influence of algae on photolysis rates of chemicals in water. Environmental Science and Technology, 1983, 17(8):462-468

[21] Esmaeili A, Sadeghi E. The efficiency of Penicillium commune for bioremoval of industrial oil. International Journal of Environmental Science and Technology, 2014, 11(5):1271-1276

[22] Farag S, Soliman N A. Biodegradation of crude petroleum oil and environmental pollutants by Candida tropicalis strain. Brazilian Archives of biology and Technology, 2011 , 54(4):821-830

[23] Dharani G, Joshi G, Kirubagaran R, Kumar A G, Peter D M, Vijayakumar L. Biodegradation of complex hydrocarbons in spent engine oil by novel bacterial consortium isolated from deep sea sediment. Bioresource Technology2014, 170:556-564

[24] Cheng M, Jiang L-H, Liu S-H, Liu Y, Niu Q-Y, Tan X-F, Xu P, Zeng G-M, Zhang C, Zhou L. Bioremediation mechanisms of combined pollution of PAHs and heavy metals by bacteria and fungi: A mini review.Bioresource Technology, 2016, 224:25-33

[25] Varjani S J. Microbial degradation of petroleum hydrocarbons. Bioresource Technology, 2017, 223:277-286

[26] Barclay C D, Farquhar G F, Legge R L. Biodegradation and sorption of polyaromatic hydrocarbons by Phanerochaete chrysosporium.Applied Microbiology and Biotechnology, 1995, 42(6):958-963

[27]Bastiaens L, Brenner V, Brennerova M, Bucheli W M, Dejonghe W, Egli T, Faber F, Hendrickx B, Junca H, Lindner A, Mau M, Pieper D H, Rüegg I, Schlömann M, Springael D, Top E M, Vosahlova J.Alternative primer sets for PCR detection of genotypes involved in bacterial aerobic BTEX degradation: Distribution of the genes in BTEX degrading isolates and in subsurface soils of a BTEX contaminated industrial site. Journal of Microbiological Methods, 2006, 64(2):250-265

[28]Kleerebezem R. Biotreatment of industrial effluents. Chemical Engineering, 2006, $113(5): 10-12$

[29] Cerniglia C E, Dean R D, Moody J. Utilization of mixtures of polycyclic aromatic 
hydrocarbons by bacteria isolated from contaminated sediment. FEMSMicrobiology Ecology, 2002, 41(1):1-7

[30] Aliasgharzad N, Assadi M M, Farazmand A, Monadi A R, Sadighbayan K. Biodegradation of naphthalene, phenanthrene and anthracene (PAHs) with bacteria in the oily soil of Tabriz. Bioscience Biotechnology Research Communications, 2016, 9(3):399-405

[31] Daba A S, Ezeronye O U. Bioremediation of textile effluent using Phanerochaete chrysosporium. African Journal of Biotechnology,2005, 4(13):1548-1553

[32] He B Y, Peng H, Qiang J, Qin H M, Ye J S, Yin H, Zhang N.Biodegradation of anthracene by Aspergillus fumigatus.Journal of Hazardous Materials, 2011, 185(1):174-181 [33] Costa G F, De Bont J A M, De Jong E, Field J A. Biodegradation of polycyclic aromatic hydrocarbons by new isolates of white rot fungi.Applied and Environmental Microbiology, 1992, 58(7):2219-2226

[34] G. Blake, F. Giraud, P. Guiraud, M. Kadri, R. Steiman. Biodegradation of anthracene and fluoranthene by fungi isolated from an experimental constructed wetland for wastewater treatment. Water research, 2001, 35(17):4126-4136

[35] Jain R K, Samanta S K, Singh O V. Polycyclic aromatic hydrocarbons: Environmental pollution and bioremediation. Trends in Biotechnology, 2002, 20(6):243-248

[36] Brar S K, Cledon M, Kadri T, Rouissi T, Sarma S, Verma M. Biodegradation of polycyclic aromatic hydrocarbons (PAHs) by fungal enzymes: A review. Journal of Environmental Sciences, 2017, 51:52-74

[37] Hatakka A, Hofrichter M, Steffen K T. Degradation of Benzo[a]pyrene by the Litter-Decomposing Basidiomycete Stropharia coronilla: Role of Manganese Peroxidase. Applied and Environmental Microbiology, 2003, 69(7):3957-3964

\section{How to cite this article:}

Abidin A N Z, Abdul-Talib S, Alias S, Tay C C. Occurrence and bioremediation of anthracene in the environment. J. Fundam. Appl. Sci., 2017, 9(6S), 214-226. 